10. Butler CC, Prout H, Kinnersley P, Rollnick S, Edwards A, Elwyn G. Shared decision making and antibiotics in primary care. Journal of Antimicrobial Chemotherapy 2001;48:435-40. http://dx.doi.org/10.1093/jac/48.3.435

11. Cals JW, Scheppers NA, Hopstaken RM, et al. Evidence based management of acute bronchitis; sustained competence of enhanced communication skills acquisition in general practice. Patient education and counseling 2007;68(3):2708. Epub 2007/08/24.

12. Butler CC, Simpson SA, Dunstan F, et al. Effectiveness of multifaceted educational programme to reduce antibiotic dispensing in primary care: practice based randomised controlled trial. BMJ 2012;344:d8173. Epub 2012/02/04.

13. Bendiks M, Kopp MV. The Relationship Between Advances in Understanding the
Microbiome and the Maturing Hygiene Hypothesis. Current allergy and asthma reports 2013. Epub 2013/08/13.

14. St S, Jacobson RM, Vierkant RA, Jacobsen SJ, Green EM, Poland GA. Association of parental vaccination reports with measles, mumps, and rubella protective antibody levels: comparison of Somali immigrant, Hispanic migrant, and US children in Rochester, Minn. Mayo Clinic proceedings 2002;77(3):241-5. Epub 2002/03/13.

15. Yoo KH, Agrawal K, Butterfield M, Jacobson RM, Poland GA, Juhn YJ. Assessment of humoral and cell-mediated immune response to measels-mumps-rubells vaccine viruses among patients with asthma. Allergy Asthma Proc 2010;31(6):499-506. http://dx.doi.org/10.2500/aap.2010.31.3399

\title{
Deprivation, winter season, and COPD exacerbations
}

\section{Gavin C Donaldson', *Jadwiga A Wedzicha1}

1 Centre for Respiratory Medicine, Royal Free Campus, University College London, London, UK

*Correspondence: Professor Wisia Wedzicha, Professor of Respiratory Medicine, Centre for Respiratory Medicine, Royal Free Campus, University College London, Rowland Hill Street, Hampstead, London, NW3 2PF, UK

Tel: +44 (0)207317 7517 Fax: +44 (0)207 4726141

E-mail:w.wedzicha@ucl.ac.uk

See linked article by McAllister et al. on pg 296

COPD exacerbations are a major cause of hospital admissions, especially during the winter months. They are mainly attributed to the increase in respiratory viral infections, though clearly other factors must also play a part. Some patients with COPD have particular susceptibility to frequent exacerbations, and this patient group is especially at risk of hospital admissions, repeat admissions, co-morbidity and deaths.'

The interesting paper by McAllister and colleagues in this issue of the $P C R J$ examines the additive effect of socio-economic deprivation on seasonal hospital admissions in COPD patients. ${ }^{2}$ The authors found a greater number of winter admissions for COPD in the most deprived compared to the least deprived quintile of the Scottish population (39 versus 7 extra admissions per 10,000 patient years between summer and winter respectively). Previous studies in England and Wales have shown no difference in excess winter deaths between areas with greater or less deprivation or colder housing. ${ }^{3-6}$ Indeed, excess winter mortality of working men aged between 50-59 years in the lowest social group (class 5) is lower than any other social class possibly because of their increased activity and that they take precautions against the cold during their manual occupations.

The findings by McAllister and colleagues can be explained by their unique approach to the question. They investigated whether the joint effect differs from the sum of the effects caused individually by temperature and deprivation. Thus, they found that patients with COPD are more likely to be admitted to hospital for an exacerbation beyond what one would expect because it is cold outside and they live in a deprived area. The cause of these extra admissions could be due to the synergistic effect of poor housing being more expensive to heat.

The study does have implications, as the demands on community care systems will be greater because more of the COPD patients discharged from hospital will be from a socio-economically deprived background. Targeting help for these patients is more problematic; interventional studies have so far failed to show any reduction in mortality or morbidity due to housing and heating upgrades, though improvements have been seen in quality of life indices. ${ }^{8}$ This may be due to the small sample size of these trials performed in the community for practical reasons. Targeting home improvement schemes just at elderly people is also politically difficult - inevitably those elderly people who live with their families will not be as high a priority.

An important limitation of McAllister et al.'s study was the use of monthly data. There are fewer admissions to hospital over the weekend and the number of weekends in each month will differ. Also, fewer patients are admitted during Christmas and the New Year periods, and this will affect the hospital admission numbers on a monthly basis. ${ }^{9}$ Cold weather also has a delayed effect on people, with peak mortality from respiratory disease occurring 12 days after peak cold. ${ }^{10}$

Though this study showed a disproportionate effect of cold weather on the most deprived, Keatinge ${ }^{11}$ reported that excess winter deaths in the general population were no different from able bodied elderly people, mainly women, living in warden controlled housing where the costs of heating did not depend on how much the resident used. However, inadequate home heating is not the only cause of winter mortality, and outdoor cold exposure is also important. ${ }^{12}$ Wearing suitable protective clothing such as a hat and gloves in cold weather is beneficial but this advice is often neglected by patients. Other reasons are that COPD may be underdiagnosed in patients with socio-economic deprivation and thus this group is more likely to develop more severe exacerbations with a respiratory infection.

McAllister and colleagues report that there were around 30\% more hospitalised COPD exacerbations in the winter than in the summer months. ${ }^{2}$ Large well designed public health interventional studies are now needed to investigate these observations further. It is likely that deprivation and season may also interact together to increase COPD exacerbations of mild to moderate severity. Therefore, 
it is possible that deprivation may contribute to under-reporting of exacerbations with less chance of treating these events. ${ }^{13}$ Meanwhile, it is important to advise patients - especially those with a history of frequent exacerbations - to take advantage of home insulation grants and to wear warm clothes when going outside the home, as this should reduce winter hospital admissions for COPD exacerbations.

Conflicts of interest The authors declare that they have no conflicts of interest in relation to this article

Commissioned article; not externally peer-reviewed; accepted 10th August 2013; online 19th August 2013

(C) 2013 Primary Care Respiratory Society UK. All rights reserved

http://dx.doi.org/10.4104/pcrj.2013.00078

Prim Care Respir J 2013; 22(3): 264-265

\section{References}

1. Wedzicha JA, Brill SE, James P Allinson JP, Donaldson GC. Mechanisms and impact of the frequent exacerbator phenotype in chronic obstructive pulmonary disease BMC Medicine 2013;11:181. http://dx.doi.org/10.1186/1741-7015-11-181

2. McAllister DA, Morling JR, Fischbacher CM, MacNee W, Wild SH. Socioeconomic deprivation increases the effect of winter on admissions to hospital with COPD: retrospective analysis of 10 years of national hospitalisation data. Prim Care Respir J 2013;22(3):296-9. http://dx.doi.org/10.4104/pcrj.2013.00066

3. Shah S, Peacock J. Deprivation and excess winter mortality. Journal of epidemiology and community health 1999;53(8):499-502.

http://dx.doi.org/10.1136/jech.53.8.499

4. Lawlor DA, Maxwell R, Wheeler BW. Rurality, deprivation, and excess winter mortality: an ecological study. J Epidemiol Community Health 2002;56(5):373-4. http://dx.doi.org/10.1136/jech.56.5.373

5. Lawlor DA, Harvey D, Dews HG. Investigation of the association between excess winter mortality and socio-economic deprivation. J Public Health Med 2000;22(2):176-81. http://dx.doi.org/10.1093/pubmed/22.2.176

6. Aylin P, Morris S, Wakefield J, Grossinho A, Jarup L, Elliott P. Temperature, housing, deprivation and their relationship to excess winter mortality in Great Britain, 19861996. Int J Epidemio/ 2001;30(5):1100-08. http://dx.doi.org/10.1093/ije/30.5.1100

7. Donaldson GC, Keatinge WR. Cold related mortality in England and Wales; influence of social class in working and retired age groups. Epidemiol. Community Health 2003;57(10):790-91. http://dx.doi.org/10.1136/jech.57.10.790

8. Liddell C, Morris, C. Fuel Povertiy and human health: A review of recent evidence. Energy Policy 2010;38:2987-97. http://dx.doi.org/10.1016/j.enpol.2010.01.037

9. Keatinge WR, Donaldson GC. Changes in mortalities and hospital admissions associated with holidays and respiratory illness: implications for medical services. J Eval Clin Pract 2005;11(3):275-81.

http://dx.doi.org/10.1111/j.1365-2753.2005.00533.x

10. Donaldson GC, Keatinge WR. Early increases in ischaemic heart disease mortality dissociated from and later changes associated with respiratory mortality after cold weather in south east England. J Epidemiol Community Health 1997;51(6):643-8. http://dx.doi.org/10.1136/jech.51.6.643

11. Keatinge WR. Seasonal mortality among elderly people with unrestricted home heating. BMJ (Clin Res Ed) 1986;293(6549):732-3.

12. Keatinge $W$, Donaldson G. Winter deaths: warm housing is not enough. BMJ 2001;323(7305):166-7. http://dx.doi.org/10.1136/bmj.323.7305.166/a

13. Seemungal TAR, Donaldson GC, Paul EA, Bestall JC, Jeffries DJ, Wedzicha JA. Effect of exacerbation on quality of life in patients with chronic obstructive pulmonary disease. Am J Respir Crit Care Med 1998;157:1418-22. http://dx.doi.org/10.1164/ajrccm.157.5.9709032

\section{Every breath you take}

\section{Liz Namukwaya', Sanctus Musafiri², *Liz Grant ${ }^{3}$}

1 Palliative Care Unit, Makerere University, Kampala, Uganda

2 Faculty of Medicine, National University of Rwanda, Butare, Rwanda

3 Global Health Academy, The University of Edinburgh, Edinburgh, UK

*Correspondence: Dr Liz Grant, Deputy Director, Global Health Academy, Medical School, Doorway 3, Teviot Place, University of Edinburgh, Edinburgh EH8 9DX, Scotland, UK Tel: +44 (0)1316514152 Fax:+44 (0)131650 9119 E-mail: Liz.Grant@ed.ac.uk

\section{See linked article by van Gemert et al. on pg 300}

Cause and effect... How much does it matter what we believe about what causes disease? And what are the implications of not making correct connections between causes and effects? The paper by van Gemert et al. ${ }^{1}$ in this issue of the PCRJ provides interesting insights into the ways in which knowledge, beliefs, and understandings about COPD and its cause and consequences determine the health and wellbeing of individuals and communities.

Chronic obstructive pulmonary disease is a major public health problem globally and a major cause of morbidity and mortality.,3 Currently the fifth leading cause of death globally, ${ }^{4}$ by 2025 it is PRIMARY CARE RESPIRATORY JOURNAL www.thepcrj.org projected to become the fourth leading cause, severely affecting those living in low and middle income countries. Increasingly poverty is identified as a risk factor for COPD, but its association with other risk factors for COPD remains unclear. ${ }^{3}$ Tobacco smoking is the wellestablished risk factor for development of COPD globally, with an estimated $80-90 \%$ risk. 5.6 The decline in lung function of susceptible smokers is twice that of non-smokers, and the pattern of cigarette smoking has changed globally, rising at a rate of $2 \%$ in low income countries. ${ }^{7}$ However, a significant number of patients with COPD, especially in low income countries in Africa, do not smoke, and the main risk factor for COPD in rural areas in Asia, South America and Africa is biomass smoke, where $90 \%$ of the rural population rely on biomass fuels for cooking. ${ }^{8-10}$ Other risk factors include previous tuberculosis (TB) infection and other respiratory infections in childhood. ${ }^{11}$

However, COPD is under-recognised in low and middle income countries by both patients and health professionals. ${ }^{3}$ This is partly due to lack of diagnostic tools, ${ }^{12}$ but it is also due to a lack of knowledge about the nature and the prognosis of the disease, and culturallyinfluenced attitudes towards the risk factors causing the disease and the symptoms of illness.

In one of the first studies of its kind, van Gemert et al. ${ }^{1}$ report the views about COPD in a rural district of Uganda, a low income country. Through 10 focus group discussions of groups of women, groups of men, and mixed groups, beliefs, attitudes and understanding of 